\title{
Effect of Corporate Social Responsibility on Firms Profitability: A Study on Small and Medium Enterprises in Pokhara City, Nepal
}

\author{
Bijay Sigdel $^{1} \&$ Fuangfa Amponstira ${ }^{2}$ \\ ${ }^{1}$ Ph.D. Candidate, Management, School of Management, Shinawatra University, Thailand \\ ${ }^{2}$ Ph.D., Management, School of Management, Shinawatra University, Thailand \\ Correspondence: Bijay Sigdel, Management, School of Management, Shinawatra University, Thailand. \\ Fuangfa Amponstira, Management, School of Management, Shinawatra University, Thailand.
}

Received: July 24, 2020

doi:10.5539/ibr.v13n10p76
Accepted: September 3, 2020

Online Published: September 17, 2020

URL: https://doi.org/10.5539/ibr.v13n10p76

\begin{abstract}
This study's main objective is to investigate the relationship between Corporate Social Responsibility and Firm's Profitability of Small and Medium enterprises located in Pokhara city, Nepal. The qualitative research design was used for the study under which the researcher collects the data by in-depth interviews through face to face interaction with the two expert government officials and fifteen owner or manager from the Small and Medium enterprises. Interviews are transcribed, coded, and interpreted to analyze the data. The study found that Ethical responsibilities are the most significant factor influencing a firm's profitability, followed by Economic responsibilities, Legal responsibilities, and Philanthropic responsibilities. Small and medium enterprises have issues in the market level, societal level, and government level that can be solved through ease in registering enterprises and improving government policy. It will bring more enterprises to the mainstream level under government subsidiaries, which will contribute more to society's betterment.
\end{abstract}

Keywords: corporate social responsibility, firms profitability, small and medium enterprises

\section{Introduction}

Corporate social responsibility (CSR) is becoming more and more important in today's world, irrespective of the types of business or organizations. It has been practicing by many business organizations to maintain a sound relationship with local and national institutions so that it may make a positive impact on customer flow and retention. The role of business organization has been changed from profit-maximizing to the responsibility towards a society where the business is responsible to the shareholders and other stakeholders (Islam, 2012). Organizational performance indicates the success of non-economic and economic goals effectively (Gyanwali \& Walsh, 2020). According to Carroll (1991), there is a hierarchy of responsibilities from economic, legal, ethical, and philanthropic. Four responsibility of CSR as defined by Carroll (1991), economic responsibilities refer to be profitable; legal responsibilities refer to obey the law provided by the government; ethical responsibilities refer to be ethical towards the society; philanthropic responsibilities refer to be a good corporate citizen who is desired by the society.

There are two reasons to investigate in CSR and Small and Medium Enterprises (SMEs). First, SMEs contribute around 22 percent of the GDP in Nepal (Bista, 2019). Second, SMEs are mostly managed by owners, and they are linked to the local community, business partner, and support to implement CSR. It has eventually affected the CSR practice adopted by SMEs, which is different from large companies (Ciliberti et al., 2008). There is the CSR policy, but the insufficient role of government hampering the implementation of CSR among SMEs. From the total population of 29.49 million, 0.41 million are fully unemployed (CEIC, 2020), and 25.2 percent live below the national poverty line (Asian Development Bank, 2020). From the above, social and economic realities are shown, so the paper has used CSR dimensions in Nepal's context.

The main backbone of the paper has been presented. First, there has been the fulfillment of the gap in the literature. Several papers have emphasized the role of CSR on companies and the banking industry (Biggs \& Messerschmidt, 2005; Adhikari et al., 2016; Upadhyay Dhungel \& Dhungel, 2013), but there are few studies related to CSR and firm's profitability on SMEs in Nepal which is the emphasis of this paper. Second, an in-depth interview method was adopted in the research. Since in-depth interview method is the most important 
and utilized instrumental tool for qualitative data collection (Guion et al., 2001; Milena et al., 2008). Finally, the paper's result can be used by managers or owners of SMEs to increase the firm's profitability by focusing more on ethical responsibilities.

The objective of the research is to determine the relationship between CSR and Firm's Profitability of Small and Medium enterprises in Pokhara city, Nepal. The paper follows the following pattern - first, the introduction of the research. Second, a literature review related to CSR and the firm's profitability. Third, a short description of the methodology. Fourth, results and discussion of the research. And Finally, conclusion and recommendation for future research.

\section{Literature review}

\subsection{Corporate Social Responsibilities Studies in Nepal}

Most of the studies related to Nepal's CSR practices mainly focus on the Banking sector (Chapagain, 2008; Rajbahak, 2016; Upadhyay Dhungel \& Dhungel, 2013; Kafle \& Tiwari, 2014). Biggs and Messerschmidt (2005) stated CSR's environmental responsibilities, like using products that are not harmful to the environment and the use of recycled fibers to manufacture handmade paper. Likewise, economic responsibilities can be fulfilled by developing an international market for the long-term growth and sustainability of the industry. Social responsibilities have been done as a code of conduct in CSR and fair trade as a result of long term socially responsible tradition in the handmade paper industry in Nepal. However, Adhikari et al. (2016) stated that CSR's economic domain includes profit earning, investment in increment, branding of the product, and customer satisfaction. The philanthropic domain includes charity and donation, poverty alleviation, Creation of employment. The economic domain includes pollution control, fair competition with the product's quality, and the right information about the product. The legal domain includes timely payment of tax to the government, complying with the rule of law to encourage the business community, and promoting pollution-free and environment-friendly business projects.

Furthermore, Chapagain (2008) reported that CSR could be used as the mean of increasing brand reputation, public image, and competitiveness of the business organization. CSR can be used for the long-term profitability of the business organization. Most of the managers have a positive view of CSR from both strategic and moral dimensions. Rajbahak (2016) revealed that whenever Nepal's commercial bank can demonstrate its good corporate social responsibility, then there will be a high chance of increasing employee determination, the firm's market value, and goodwill. However, Upadhyay Dhungel and Dhungel (2013) study found that CSR has not been made mandatory in Nepal, and all the banks are doing it involuntary basis. The major activities performed by banks in Nepal are aiding in education, training, healthcare, environment, games and sports, blood donation, sponsorship, etc. As stated in Chapagain (2010), both the financial and manufacturing sectors have a strong involvement with shareholders, customers, competitors, and government aspects of CSR but have weak involvement in the social aspect of CSR. CSR has been an ongoing trend that thinking has moved from philanthropy to competitive advantage and stakeholder relations of the organization.

In addition, Pant and Piansoongnern (2017) stated that organizations are providing donations in the flood, earthquake, and community welfare activities as a part of CSR. The CSR initiatives have been increasing the brand image, customer loyalty, support from stakeholders, and the company's market share. However, Baniya et al. (2019) stated that CSR perceptions are linked with benefits, comparative, and favorability, which affected CSR's true assessment. Finally, Kafle and Tiwari (2014) state the CSR involvement in the activities related to blood donation programs, sports, community support, health facilities, poverty alleviation, and the environment. However, there is limited research done on the relationship between CSR and firm profitability among SMEs in Nepal. So, this research will contribute to finding a link between CSR and firm's profitability among SMEs in Nepal.

\subsection{CSR and Firm's Performance in SMEs}

Corporate Social responsibility can be defined as the organization management's practice to ensure that there should be a positive impact on society by generating employees and satisfying the customer need. In this study, Agyemang and Ansong (2017) stated that there is a significant and positive relationship between CSR activities and firm performance (Sales growth, profit growth, and Leverage) of SMEs in Ghana. However, Conesa et al. (2017) focus on the measures of five dimensions of CSR, which are (customers, suppliers, local community, employees, and environmental responsibility) and relationship with innovation and firm performance using structural equation modeling on Spanish SMEs. The effect of CSR on a firm's performance can be improved through an increase in innovation. In the context of Torugsa et al. (2012), the study focuses on the measure of three specific capabilities (stakeholder management, strategic proactivity, shared vision), proactive CSR, and financial performance (return on assets and net profit of sales) in SMEs using structural equation modeling with LISREL 8.8. There is a significantly 
positive relationship between proactive CSR and SME's financial performance.

Furthermore, Maldinado-Guzman et al. (2016) concluded that social, economic, and environmental components are good predictors of SMEs' social responsibility. If SMEs want to adopt social responsibility, then they should not only be thinking about the benefit of its clients, workers, employees, suppliers, and society but should focus on environmental well-being. It is pervasive that any business organization's main goal is to increase profit and accomplish its goals and objectives. Especially in SMEs, they use CSR to do so by showing a high level of social responsibility. There is a significant and positive relationship between CSR and business performance of the organization. Similarly, Yang et al. (2017) stated that there is a positive relationship between internal CSR and financial performance. The corporate's financial performance can be improved directly from safety and healthy work environment, developing employees' skills and career, providing good training of employees, and a safe working place.

Also, Gorondutse and Hilman (2014) study that there is a significant relationship between the commitment of business social responsibility and the small-scale industry's performance in Nigeria. Similarly, Choongo (2017) focuses on the measure of CSR (environmental and social) and firm performance (financial performance, corporate reputation, employee commitment). The two dimensions of CSR (environmental and social) significantly impact financial performance but partially significant with the organization's reputation and employee commitment. However, there has been limited research between CSR and firm performance among SMEs in Nepal that this research fulfilled.

\subsection{CSR in SMEs}

Corporate social responsibility is the concept that when a company earns some profit, there should be a contribution to society to develop both the society and the country. In the context of Sweeney (2007), CSR defined by SMEs is to conduct business responsibly and contribute towards the local community for its well-being. The most barrier mentioned by SMEs was financial constraints. SMEs' opportunities in the context of CSR are mentioned as follows: first, SMEs can easily build a good relationship with the customer, government, and community. Second, small firms are more flexible and provide a quick response to stakeholders' demand by implementing stakeholders' policies. As stated in Inyang (2013), SMEs' involvement in CSR is important to create economic growth, provide an opportunity for income in society, and promote private sector development and employment opportunities. There are several benefits of CSR engagement for SMEs, such as improvement in employee loyalty, positive impact in business growth, building healthy community relations, and profitability. SMEs' role is associated with employee initiatives, community development, environmental actions, consumerism, and supply chain requirements.

Furthermore, Coppa and Sriramesh (2013), most CSR activities in Italian SMEs, are employee empowerment and development, employee training, and employee welfare. The most important factor that motivates SMEs for CSR is an improvement in public welfare and long-term sustainability. The most important stakeholders for CSR communication are employees, customers, suppliers, and business partners. However, Amaeshi et al. (2016) stated that CSR activities among Sub Saharan African SME's efforts are beyond philanthropy. CSR practices are more valuable in such areas as there is a lack of public action and relation. CSR involvement among SMEs is carried in the marketplace, workplace, local community, and ecological environment.

Also, Nejati \& Amran (2009), most of the companies are not reaping the benefits when conducting CSR activities, but they were continuing to do so for their values and belief. SMEs owners are engaged in environmentally friendly practices for well-being in association with customers, consumers, local community groups, suppliers, investors, and environmental groups. However, Perrini et al. (2007) show that large firms are more likely to report environmental management, controlling, and employment, but SMEs recognize the importance of the supply chain. SMEs and large firms still support community volunteering. It is further suggested that they should undertake more formal CSR strategies when there is a larger firm.

\section{Methodology}

The research involved qualitative research design (Bryman, 2016) and in-depth interviews (Guion et al., 2001; Milena et al., 2008) using face to face interaction. The research population was collected from Pokhara and Lekhnath Chamber of Commerce and Industry and Department of Cottage and Small industries to find out the registered Small and Medium Enterprises (SMEs). The research sample includes two higher-ranking experienced government officials and 15 SMEs owner or managers in Pokhara city, Nepal. The research sample was taken from (Creswell, 2016) where sample size varied from 5 to 25 persons. The item objective congruence (IOC test) was done using the expert before going to the field for data collection. The data were transcribed, coded, and interpreted to analyze the data. Most of the questionnaire was designed from (Carroll, 1991). Performance in 
terms of profitability influencing factors and CSR practice is explored from the interview opinion.

\section{Results and Discussion}

\subsection{Activities Related to Corporate Social Responsibilities}

The analysis was done to identify the activities related to corporate social responsibility among small and medium enterprises:

\subsubsection{Employee Benefit}

Employee benefit is the facilities provided to employees by the small and medium enterprises to improve their status and motivate them to provide good service to the customer. The facilities provided to the employees by small and medium enterprises are provident funds for their retirement plan, free checkup and medical expenses, free training programs which will help the company to develop new product development, providing rental facilities inside the boundary of the company, and providing education to employee families.

\subsubsection{Donation Program}

The donation program is activities related to contributing to society and improving society's standards. Programs include a blood donation program which will help reduce the crisis of blood in Nepal, providing a donation in terms of money, clothes, food, tents in natural calamities, health camp for the better health of people living in society, contribution in the construction of roads for the better facilities to the society.

\subsubsection{Social Activities}

Social activities are those activities that contribute towards the desire of the society that contributes to developing the economy and profitability of small and medium enterprises. Activities that include social activities are as follows providing sponsors to different events like sports, concerts, fair, and so on, scholarship to poor students, employing poor and hardworking people, empowering people by providing machines to help them survive, providing the equipment needed for the disabled people.

\subsubsection{Environmental Activities}

Environmental activities create awareness towards environmental issues in society and aim to make efficient use of natural resources. Activities include a tree plantation program to contribute to climate change, prevent soil erosion, decrease pollution, and clean around the surrounding.

\subsubsection{Quality Products}

The quality of the product helps to increase the goodwill of the small and medium enterprises, increased sales, customer satisfaction, and increase loyal customers. Quality of product has been provided to the customer to show customers that small and medium enterprises are ethical towards society.

There are many activities related to CSR in small and medium enterprises as follows employee benefit, donation program, social activities, environmental activities, and quality of the product.

\subsection{Indicators of Legal Responsibilities}

The analysis was done to identify the indicators related to corporate social responsibility's legal responsibilities:

\subsubsection{Product Quality Inspection}

Product quality inspection is a process to check whether the product meets the quality requirement or not. It covers proper labeling and packaging, carton drop test, and functional testing. The Manufacturing industry of small and medium enterprises refers to the quality of the product by testing the products and getting acceptance from the government for the packaging of products. For the quality of the product in the manufacturing industry, there has been the renew of machine and check-in quality maintenance that will increase the efficiency of the machine and provide the good quality of the product.

\subsubsection{Legal Standards}

The legal standard is set into governmental laws and written by governmental officials. In small and medium enterprises, the legal standard can only be fulfilled by a collection of signatures from neighbors before registration, and then there will be registration in every government office that is needed. In every enterprise, they are paying tax at every end of the month after the audit, and then only the enterprise can be renewed. Small and medium enterprises are fulfilling the labor laws include the number of employees in terms of the rules and regulations provided by the government and paying salary higher than government policy. 


\subsubsection{Environmental Laws}

Environmental laws are mainly known as natural resources law that will protect the environment from damage. There are many small and medium enterprises that are focusing on environmental issues like air pollution, the health of people, the use of plastic, and sound pollution. They are focusing on cleaning the environment and doing tree plantation programs to make the environment good for society.

As per the discussion, product quality inspection, legal standard, and environmental laws are the key indicators of legal responsibilities of corporate social responsibility.

\subsection{Indicators of Philanthropic Responsibilities}

The analysis was done to identify the indicators related to Philanthropic responsibilities of corporate social responsibility are presented below:

\subsubsection{Donation}

Donation is special money, food, clothes that are given to the charity that will help a person or society. The small and medium enterprise focuses on donation because it requires less money and can be done voluntarily. The donation has been made in many public awareness programs, providing education to the genuine student and school development. There is a unique way to provide donations in programs related to encouraging and promoting new entrepreneurs, promoting tourism like the Nepal 2020 sticker in the water bottle. There have been owners' activities towards society, like donations in proper road facilities and loans provided from enterprises with no interest rate.

\subsubsection{Competitive Salary}

A competitive salary is in that company who can pay a salary above the competitor's market rate or salary for similar work in the same location. There has been a competitive salary in the company to encourage employee loyalty and promote employee engagement to increase firm profitability. Most of the small and medium enterprises working in the technical field explained that there had been a competitive salary because there are fewer workers involved in the technical field and hard to find the new employee who is highly experienced.

\subsubsection{Job Training Programs}

Training programs are mostly designed to help employees gain their knowledge and develop their career of individual and organization growth. Small and medium enterprises mainly provide free training to employees who are in training period of job and provided a salary to them, those who are interested in innovation of new strategy when launching a new product and when adopting new technology. An increase in job satisfaction and employee motivation is the benefit of job training programs to increase profit.

As per the discussion, Donation, Competitive salary, and Job training programs are the key indicators of Philanthropic Responsibilities of corporate social responsibility.

\subsection{Indicators of Economic Responsibilities}

The analysis was done to identify the indicators related to Economic responsibilities of corporate social responsibility are presented below:

\subsubsection{Respond to a Customer Complaint}

A customer complaint is an issue bought by the customer to find a solution through the company. Small and medium enterprises will help to improve the customer experience in the future and show customers that the company is planning or already find the solution. There is a quick response as soon as possible to customer complaints through troll no provided in the product packet. Small and medium enterprises have an advantage while responding to customer complaints is an increase in customer loyalty, a better understanding of customers, and improved communication with the customer.

\subsubsection{Market Expansion}

Market expansion is mostly explained by the business growth strategy where business can be increased. In small and medium enterprises, there is an increase in the market by increasing investment by the owner of the enterprise to attract new customers. They focus on marketing by showing their product in the industrial business fair to have a wider customer base. They focus on increasing profit by market expansion to create opportunities and to increase the customer base.

\subsubsection{Quality of the Product}

The product's quality is the product that meets the expectation of customers and meets competition in the 
marketplace. In small and medium enterprises, they focus on the good quality of input to get a good quality of output to increase the price. Selling products like water is a sensitive product that should have a good quality because it is mostly related to health issues, which will establish a reputation for the customer. The production of the product is shown to the people and field visits of students so that they can be aware of the product quality issues to increase customer satisfaction.

\subsubsection{Stakeholders Satisfaction}

Stakeholder's satisfaction includes customer and employee satisfaction. In Small and medium enterprises, customer satisfaction who reported experience with the firm, its services, and products exceed the satisfaction goal. Employee satisfaction is whether employees are happy by fulfilling their needs and desire at work will increase productivity and less job stress. Customer satisfaction through motivation leads to increased sales, increased profit, increased word of mouth, stable sales revenue, and a stronger relationship between staff and customers.

As per the discussion, respond to customer complaints, market expansion, quality of the product, and stakeholder satisfaction are key indicators of corporate social responsibility's economic responsibilities.

\subsection{Indicator of Ethical Responsibilities}

The analysis was done to identify the indicators related to Ethical responsibilities of corporate social responsibility are presented below:

\subsubsection{Correct Information to Customers}

Customer retention and satisfaction are the most important component of a healthy and successful business. That can only be gained through correct information provided to customers. In small and medium enterprises, they focus on society's concept of the company is good, so they provide the information like date of expiry, ingredients used in the product, the weight of the product, and how to use the product. There is an increase in trust and loyalty of customers towards the enterprises with the help of correct information to the customer that leads to an increase in firm profitability.

\subsubsection{Fair Employee Evaluation}

Fair employee evaluation is a way that will increase the trust of employees towards the company and satisfy the employees to increase firm profitability. Small and medium enterprises often talk with employees weekly or monthly and provide more and more feedback to them. The owner or manager gives the employee a chance to express their perspectives and let the employee know that owner or manager are interested in employees view.

\subsubsection{Trustworthy Company}

A trustworthy company is a reputed company that can be reliable and trusted. Small and medium enterprises are mostly providing quality products or improving products' quality to increase customer satisfaction and loyalty towards the enterprises that will lead customers to trust the enterprises. Employees are provided health insurance, housing facilities that will increase employees' trust towards the enterprises and lead to an increase in firm profitability. They build their employees in their company by providing training to them rather than hiring employees from other companies to provide trust to the employees.

As per the discussion, Correct information to customers, fair employee evaluation, and trustworthy company are the key indicators of corporate social responsibility's ethical responsibilities.

\subsection{Most Important Dimension of CSR and the Firm's Profitability}

The analysis was done to identify the most important dimension of CSR is presented below:

\subsubsection{Ethical Responsibilities}

In today's business environment, managers or workers are expected to do what is right and fair to avoid harming others. In small and medium enterprises, to have a positive image of business must commit to operating in an ethical foundation. It relates to fair market practice in price and customer treatment, showing respect to the surrounding environment and treatment of employees to increase firm profitability. In small and medium enterprises providing correct information, fair evaluation of employees, and becoming a trustful company has been the most important factor in increasing firm profitability.

\subsubsection{Economic Responsibilities}

The basic responsibility of a business organization is to increase its profit to the maximum point that contributes to shareholders and the country's economy. In small and medium enterprises, components like providing quick 
responses to customers, good quality of the product, and customer satisfaction are the most important factor to increase firm profitability. Economic responsibility is important because if the enterprise is not in profit, then the enterprise cannot meet other responsibilities towards society.

\subsubsection{Legal Responsibilities}

Legal responsibilities are the responsibility to obey the rules and regulations of the government. In Nepal's Small and Medium enterprises, they are following the rules like collecting the signatures from neighbors before registration, paying tax at the end of the month, and then renewing the enterprises. There has been testing the quality of the product, renewal of the machine, and check-in quality maintenance.

As per the discussion, the most important dimension is Ethical responsibilities followed by Economic responsibilities and Legal responsibilities of corporate social responsibility.

\subsubsection{Profitability}

Profitability has been measured on a Likert scale 1: Very low profit, 2: Low profit, 3: Normal profit, 4: High profit, 5: Very high profit. Most of the respondent describe as there is normal profit due to the growing stage in the market followed by high profit due to increase in sales with high margin, low profit due to competition in the market, very high profit due to enterprises mostly focuses on profit and very low profit due to high expenses.

\subsection{Problems and Ways to Improve SMEs' Effective Performance}

An investigation was made on identifying the problem faced by SMEs, and the solution to the problem from the side of SMEs and government is presented below:

\subsubsection{Market Issue}

There is a more negative impact on the market for small and medium enterprises where society only sees the negative part of the enterprises, not the positive impact in society. Some small and medium enterprises are not registered yet to pay government tax and have not to focus on corporate social responsibility that creates a negative impact on all small and medium enterprises in the market. The solution for this is the government should act quickly about the tax policy and make the market competitive. Government officials should focus on if the company is registered or not. The government should help the company grow by providing them facilities when they are in bad condition to make a positive impact on the market of small and medium enterprises. Motivating small and medium enterprises by taking the name of the company in a mass of people. Government officials ensure that the company that is not registered yet will be closed and must pay tax according to the government policy.

\subsubsection{Society Issue}

There is a high expectation of society beyond the budget of an enterprise. The budget is allocated according to the company's profit or investment, and there is less investment in small and medium enterprises. There is an expectation of society, and enterprises are limited to program like health camp and blood donation. The solution for this is there is more expectation of society. Still, society should be aware of the company's investment and profit so that they can ask according to the company's budget. Society should expect new ideas in small and medium enterprises like promote new entrepreneurs and unite with the society to have a unique idea to develop a society. Government officials explain that they are planning to increase small and medium enterprises to contribute to society.

\subsubsection{Government Issue}

There is a corporate social responsibility policy according to the foreign country that creates a misunderstanding between the government and small and medium enterprises. Government officials did not think about the condition of enterprises in Nepal for the contribution towards society. Lack of education in small and medium enterprises has been seen because of a lack of government providing the importance of technical employees. Some employees have technical knowledge that goes abroad for their work, and there is a lack of employees in Nepal. The owner or manager has less information about the Corporate social responsibility towards society. Focus that there is a lack of information and lack of employees in small and medium enterprises. The problem is a conflict between the government and small and medium enterprises about the policy. The solution for this is that the government should have its policy. That should be applicable for every small and medium enterprise like they can categorize the responsibility according to the investment or the profit of the enterprises to be involved in corporate social responsibility. Training programs should be provided by the government to technical employees and motivate them to work in own country because it will decrease the cost of small and medium enterprises and it will help to fulfill the need of employee as well as it will encourage owner or manager to invest more in corporate social responsibility. To provide education and flow of information to small and medium 
enterprises about corporate social responsibility should be clear and motivate enterprises to do it.

As per the discussion, market issues, social issues, and government-issue are the major problem while implementing corporate social responsibility.

\section{Conclusion and Recommendation}

There are many activities related to corporate social responsibility that has been done by small and medium enterprises where most of the activities related to donation program followed by an employee benefit, social activities, environmental activities, and less preferred activities are quality of the product. There is three most important conclusion as follows. First legal responsibilities, most enterprises prefer legal standards to be fulfilled and followed by product quality inspection and environmental laws to be executed. In philanthropic responsibilities, most enterprises prefer donations followed by job training programs and a competitive salary. In Economic responsibilities, most enterprises prefer the quality of products followed by stakeholder's satisfaction, market expansion, and customer complaints. In ethical responsibilities, most enterprises prefer a trustworthy company followed by correct information to customers, fair employee evaluation. Second, Adhikari et al. (2016) concluded that there is a change from the philanthropic domain to the economic domain. However, in this study, ethics is the most important factor followed by economic, legal, and philanthropic responsibilities. Third, small and medium enterprises have issues in the market level, societal level, and government level that can be solved through ease in registering enterprises and improving government policy. It will bring more enterprises to the mainstream level under government subsidiaries, which will contribute more to society's betterment. In a further research study of CSR on a large scale, the result may be different from this research. The research should include quantitative and qualitative methods so that the research will be more effective.

\section{References}

Adhikari, D. R., Gautam, D. K., \& Chaudhari, M. K. (2016). Corporate social responsibility domains and related activities in Nepalese companies. International Journal of Law and Management. https://doi.org/10.1108/IJLMA-08-2015-0044

Agyemang, O. S., \& Ansong, A. (2017). Corporate social responsibility and firm performance of Ghanaian SMEs. Journal of Global Responsibility. https://doi.org/10.1108/JGR-03-2016-0007

Amaeshi, K., Adegbite, E., Ogbechie, C., Idemudia, U., Kan, K. A., Issa, M., \& Anakwue, O. I. (2016). Corporate social responsibility in SMEs: a shift from philanthropy to institutional works? Journal of business Ethics, 138, 385-400. https://doi.org/10.1007/s10551-015-2633-1

Asian Development Bank. (2020). Poverty Data: Nepal. Retrieved May 15, 2020, from https://www.adb.org/countries/nepal/poverty

Baniya, R., Thapa, B., \& Kim, M. S. (2019). Corporate Social Responsibility Among Travel and Tour Operators in Nepal. Sustainability, 11, 2771. https://doi.org/10.3390/su11102771

Biggs, S., \& Messerschmidt, D. (2005). Social responsibility in the growing handmade paper industry of Nepal. World Development, 33, 1821-1843. https://doi.org/10.1016/j.worlddev.2005.06.002

Bista, I. (2019). SMEs Financing in Nepal: Five key findings of the report. Nepal Economic Forum.

Bryman, A. (2016). Social research methods. Oxford university press.

Carroll, A. B. (1991). The pyramid of corporate social responsibility: Toward the moral management of organizational stakeholders. Business horizons, 34, 39-48. https://doi.org/10.1016/0007-6813(91)90005-G

CEIC. (2020). Nepal Unemployment Rate. Retrieved May 15, 2020, from https://www.ceicdata.com/en/indicator/nepal/unemployment-rate

Chapagain, B. R. (2008). Management views on corporate social responsibility in commercial banks of Nepal. Socio Economic Development Panorama, 1, 119-130.

Chapagain, B. R. (2010). Corporate social responsibility: evidence from Nepalese financial service and manufacturing sectors. Economic Journal of Development Issues, 9-20. https://doi.org/10.3126/ejdi.v11i0.6103

Choongo, P. (2017). A longitudinal study of the impact of corporate social responsibility on firm performance in SMEs in Zambia. Sustainability, 9, 1300. https://doi.org/10.3390/su9081300

Ciliberti, F., Pontrandolfo, P., \& Scozzi, B. (2008). Investigating corporate social responsibility in supply chains: a SME perspective. Journal of cleaner production, 16, 1579-1588.

https://doi.org/10.1016/j.jclepro.2008.04.016 
Conesa, I. M., Soto-Acosta, P., \& Manzano, M. P. (2017). Corporate social responsibility and its effect on innovation and firm performance: An empirical research in SMEs. Journal of cleaner production, 142, 2374-2383. https://doi.org/10.1016/j.jclepro.2016.11.038

Coppa, M., \& Sriramesh, K. (2013). Corporate social responsibility among SMEs in Italy. Public relations review, 39, 30-39. https://doi.org/10.1016/j.pubrev.2012.09.009

Creswell, J. W. (2016). Qualitative inquiry and research design: Choosing among five approaches. Sage publications.

Gorondutse, A. H., \& Hilman, H. (2014). Meditation Effect of Organizational Culture on the Relationship between Commitments of Business Social Responsibility (BSR) on Performance of SMEs: Partial Least Square (PLS) Approach. European Journal of Social Sciences, 41, 624-638.

Guion, L. A., Diehl, D. C., \& McDonald, D. (2001). Conducting an in-depth interview. University of Florida Cooperative Extension Service, Institute of Food and Agriculture Science, EDIS.

Gyanwali, S., \& Walsh, J. C. (2020). Influencing Factors of Organizational Performance in Nepal Airlines Corporation. International Business Research, 13, 268-283. https://doi.org/10.5539/ibr.v13n1p268

Inyang, B. J. (2013). Defining the role engagement of small and medium-sized enterprises (SMEs) in corporate social responsibility (CSR). International business research, 6, 123. https://doi.org/10.5539/ibr.v6n5p123

Islam, K. Z. (2012). Corporate social responsibility (CSR) and issue to corporate financial performance (CFP): an empirical evidence on Dhaka stock exchange (DSE) listed banking companies in Bangladesh. European Journal of Business and Management, 4, 18-26.

Kafle, P., \& Tiwari, D. (2014). The assessment of a nepalese bank in terms of corporate social responsibility (CSR). ASSESSMENT, 2, 28-34.

Maldonado-Guzman, G., Pinzon-Castro, S. Y., \& Lopez-Torres, G. C. (2016). Corporate social responsibility and business performance: The role of Mexican SMEs. International Journal of Asian Social Science, 6, 568-579. https://doi.org/10.18488/journal.1/2016.6.10/1.10.568.579

Milena, Z. R., Dainora, G., \& Alin, S. (2008). Qualitative research methods: A comparison between focus-group and in-depth interview. Annals of the University of Oradea, Economic Science Series, 17, 1279-1283.

Nejati, M., \& Amran, A. (2009). Corporate social responsibility and SMEs: exploratory study on motivations from a Malaysian perspective. Business strategy series. https://doi.org/10.1108/17515630910989150

Pant, D. R., \& Piansoongnern, O. (2017). Impact of Corporate Social Responsibility on Sustainable Competitive Advantage: A Case Study of Leading Noodle Companies in Nepal. International Journal of Social Sciences and Management, 4, 275-283. https://doi.org/10.3126/ijssm.v4i4.17940

Perrini, F., Russo, A., \& Tencati, A. (2007). CSR strategies of SMEs and large firms. Evidence from Italy. Journal of business ethics, 74, 285-300. https://doi.org/10.1007/s10551-006-9235-x

Rajbahak, S. (2016). Corporate social responsibility (CSR) and firm value: A case study of Nepalese Commercial Bank. NEPALESE JOURNAL OF BUSINESS, 3, 171.

Sweeney, L. (2007). Corporate social responsibility in Ireland: barriers and opportunities experienced by SMEs when undertaking CSR. Corporate Governance: The international journal of business in society. https://doi.org/10.1108/14720700710820597

Torugsa, N. A., O’Donohue, W., \& Hecker, R. (2012). Capabilities, proactive CSR and financial performance in SMEs: Empirical evidence from an Australian manufacturing industry sector. Journal of business ethics, 109, 483-500. https://doi.org/10.1007/s10551-011-1141-1

Upadhyay Dhungel, K., \& Dhungel, A. (2013). Corporate social responsibility reporting practices in the banking sector of Nepal. Banking Journal, 3, 61-78. https://doi.org/10.3126/bj.v3i1.7511

Yang, L., Yaacob, Z., \& Teh, S. Y. (2017). Does Reputation Mediate the Relationship between Corporate Social Responsibility and Performance of SMEs in China. International Journal of Economics \& Management, 11.

\section{Copyrights}

Copyright for this article is retained by the author(s), with first publication rights granted to the journal.

This is an open-access article distributed under the terms and conditions of the Creative Commons Attribution license (http://creativecommons.org/licenses/by/4.0/). 